\title{
Validity of coliphages as indicators of viral pollution of water in the Aral Sea area, Uzbekistan
}

\author{
D. K. Fayzieva, I. A. Usmanov, E. E. Bekzhanova, \\ F. B. Kadirkhodjaeva \& F. B. Shadijanova \\ Institute for Water Problems, Academy of Sciences, Uzbekistan
}

\begin{abstract}
Hygienic standards of microbial contamination of water in water-bodies for different types of water consumption have been developed to prevent intestinal infections amongst the population. The current methods of microbiologic examination of water in water-bodies used for different types of water sources in Uzbekistan do not always meet the ISO requirements. This sets the goals of studying the validity of the bacteriological and viral indicators as well as implementing appropriate methods of laboratory analysis.

Timely identification of microbial contamination of water is of special importance for correct and quick arrangement of anti-epidemic and sanitation activities. Among all other activities aimed at the reduction and prevention of viral infections, early and prompt identification of viral pollution of water is of top priority. According to the Uzbek State Standard 950:2000 "Drinking Water" a number of plague forming units (PFU) of coliphages in water was recommended as an indirect indicator of water pollution by enteroviruses.

The study conducted in Khorazm and Karakalpakstan (in the Aral Sea area) could find no correlation between the rate of viral hepatitis A (VHA), percentage of tap-water samples that do not meet the standard and the quality of water from surface water-bodies tested for coliphages. This makes questionable the sanitary-indicative value of coliphages and their usefulness for evaluation of epidemiological safety of water regarding viral infection.

It is necessary to set modern and more representative direct methods revealing the indicators of viral pollution of water in water-bodies and tap-water in Uzbekistan.
\end{abstract}

Keywords: water pollution, indirect indicators of viral contamination, coliphages, the Aral Sea area. 


\section{Introduction}

Given the fact that even one viral unit of few viruses is able to cause of serious case of disease, the evidence of their presence in water should be provided [1]. The results of last investigations show, coliphages can not represent itself as indicators of virus pollution of water, as their presence not always correlates with presence of the virus agents $[2,3,4,5]$. It was demonstrated that if to test water-samples for the presence of enteroviruses, antigens of viral hepatitis A and rotaviruses, the number of even of tap-water samples defined as unsafe water by the microbiological indicators can rise by $30-40 \%[2,3]$. The enteroviruses can be isolated from water on a background when coliphages are not detected ( $\sim$ in 2-3\% of assays) [2]. All above stated puts under doubt sanitary - indicative importance of coliphages and opportunity of their use while estimation of epidemic safety of water concerning virus infections $[3,4,5]$.

Now identification of viral pollution of water in water-bodies is being regulated in Uzbekistan by the State Standard Uz 950:2000 "Drinking water" that recommends to use number of plague forming units (PFU) of coliphages in water as an indirect indicator of its viral pollution [6]. However, no special research was conducted in the country to study the indicator value of PFU of coliphages.

The objectives of the present research was to study the dynamics of viral hepatitis A rate among the population of Khorezm province and the Republic of Karakalpakstan (the Aral Sea area) and to find its correlation with the quality indicator of water, namely the coliphages level in water-bodies of different types of water-consumption.

\section{Data and methods}

Hepatitis A morbidity has been analyzed on its rate (per 100,000 of population) among the population of areas under study. Every case of the disease or a suspected case registered in official reporting documents was taken as a unit of evaluation. The percentage of water-samples with coli-phages was calculated in every area under study. The statistic materials of the province centers for sanitary and epidemiological surveillance for 2000-2004 were used.

\section{Results}

As Table 1 shows, viral hepatitis A (VHA) rates are still high in the areas under study. The intensive indicator of VHA morbidity in Khorezm province was 375.9 in 2000 having reduced by 2004 to 287.6 per 100,000 of population. In Karakalpakstan, in 2000 it was 464.9 having reduced in 2004 to 356.6 per 100,000 of population.

During the whole period of the research the percentage of tap-water samples that did not meet the standard by the presence of coliphages had ranged from 3.8 to 5.7 per cent. The fact of coliphages identification in tap-water indicated both insufficient sanitary and technical efficiency of the facilities and insufficient 
sanitary surveillance of their functioning (Table 2). The share of non-standard by coli-phages samples in water of surface water-bodies was large and ranged from 14 to 34 per cent (Table 3 ).

Table 1: Dynamics of VHA morbidity rates among the population of the Aral Sea area (per 100,000 of population).

\begin{tabular}{|l|c|c|c|c|c|}
\hline \multirow{2}{*}{\multicolumn{1}{|c|}{ Provinces }} & \multicolumn{5}{|c|}{ Years } \\
\cline { 2 - 6 } & 2000 & 2001 & 2002 & 2003 & 2004 \\
\hline \multirow{2}{*}{ Khorazm } & 375.9 & 394.6 & 415.0 & 384.4 & 287.6 \\
Karakalpakstan & 464.9 & 398.4 & 657.1 & 397.8 & 356.6 \\
\hline
\end{tabular}

Table 2: Findings of the sanitary and virological analysis of tap-water in the Aral Sea area

\begin{tabular}{|c|c|c|c|c|}
\hline \multirow[b]{2}{*}{ Province } & \multirow[b]{2}{*}{ Years } & \multicolumn{3}{|c|}{ plaque-forming units of coliphages } \\
\hline & & $\begin{array}{c}\text { Number } \\
\text { of samples }\end{array}$ & $\begin{array}{c}\text { Among them } \\
\text { positive } \\
\text { samples }\end{array}$ & $\begin{array}{c}\% \text { of } \\
\text { positive } \\
\text { samples }\end{array}$ \\
\hline \multirow[t]{3}{*}{ Khorazm } & 2000 & 250 & 11 & 4.4 \\
\hline & 2002 & 215 & 12 & 5.6 \\
\hline & 2004 & 196 & 8 & 4.1 \\
\hline \multirow[t]{3}{*}{ Karakalpakstan } & 2000 & 310 & 12 & 3.8 \\
\hline & 2002 & 280 & 16 & 5.7 \\
\hline & 2004 & 295 & 14 & 4.7 \\
\hline
\end{tabular}

Table 3: $\quad$ Share of non-standard by coliphages water-samples from surface water-bodies (river, irrigation ditch) in the Aral Sea area.

\begin{tabular}{|l|r|r|c|c|c|}
\hline \multirow{2}{*}{ Province } & \multicolumn{5}{|c|}{ Years } \\
\cline { 2 - 6 } Khorazm & 2000 & 2001 & 2002 & 2003 & 2004 \\
\hline \multirow{5}{*}{ Karakalpakstan } & 30.0 & 14.0 & 18.0 & 17.2 & 16,5 \\
\hline
\end{tabular}

In the epidemiology of viral hepatitis A, the leading etiologic role is played by a "water factor" that is why we have studied the correlation between the VHA rates among the population and the share of non-standard by coliphages 
water-samples in tap-water and in water of open sources i.e. from surface waterbodies (river, irrigation ditch).

The findings shown in Table 4 demonstrate a significant scattering of the correlation coefficient depending on the type of water-consumption in the areas under study. Poor correlation was found between the VHA rates in Khorezm province and the percentage of non-standard samples: for tap-water it was 0.37 ; for surface water-bodies -0.39 . The similar data were obtained when treating the findings obtained in Karakalpakstan. In this area, the correlation coefficients were 0.40 and 0.35 , respectively.

Table 4: Correlation coefficients between the VHA rates in population and the share of non-standard by coliphages water samples (\%).

\begin{tabular}{|c|c|c|}
\hline Province & Tap water & Open sources \\
\hline Khorazm & 0.37 & 0.39 \\
\hline Karakalpakstan & 0.40 & 0.35 \\
\hline
\end{tabular}

Thus, the research of coliphages failed to evaluate objectively viral pollution of water in different types of water-consumption. This makes questionable the sanitary-indicative value of coliphages and their usefulness for evaluation of epidemiological safety of water regarding viral infection.

A certain part in this is, probably, played by imperfection of the existing methods identifying coliphages because they are made using agar-layers. This method implies identification of the number of plaque-forming units in $1.5 \mathrm{ml}$ of water-sample in which enterobacteria are able to give negative colonies on the bacterial "lawn". It is evident that in order to raise representativeness of the method it is necessary to work out a specific technique that would imply concentration of certain volumes of water, the minimum volumes being 100 and 1000 litres.

It should be also taken into account that the existing method is indirect while the only reliable method to have virologically safe water is to eliminate human pathogenic viruses that can be identified by direct virological tests.

\section{Conclusions}

Ensuring epidemiological safety of water regarding human viral infection requires up-dating the indicators and order of sanitary and epidemiological surveillance of water quality for different types of water-consumption.

Modern and representative indicators of viral pollution of water used for drinking and household needs have to be studied in local conditions and implemented into practice.

Amendments to the existing regulating documents and instructions used in the practice of virological laboratories within the system of the state sanitary and epidemiological surveillance of environment need to be made. 


\section{Acknowledgements}

This investigation was carried out in the frame of the research project No 13.40 on "Ecological and epidemiological assessment of anthropogenic impact on drinking water sources", in 2003-2005, funded by the State Scientific and Technology Program of the Republic of Uzbekistan. Authors express their gratitude to the Center of Science and Technologies at the Cabinet of Ministers of the Republic of Uzbekistan for given opportunity in organization of the investigation on validity of coliphages as indicators of water pollution by viruses. We feel sincere gratitude to the Embassy of France in Uzbekistan for great support in organization of expert evaluation travel to the Aral Sea area and study of local laboratory conditions and data on microbial water quality and water-borne diseases rates in collaboration with Head of Environment and Water Department of Pasteur Institute in Lille, Dr. Tristan Simonart in AugustSeptember of 2003.

\section{References}

[1] Vinogradova L.A., Luzin, P.M., Korovka, V.G. Urgent problems of medical virology, pp. 69-72, Moscow, 1985.

[2] Amvrosieva, T.V., Diakonova, O.V., Poklonskaya, N.V. To a problem of an adequate estimation of epidemic safety of water concerning viral infections. Proceedings of the $4^{\text {th }}$ International Congress: "Water, Ecology, Technology - ECWATECH”, p.740-741, Moscow, 2000.

[3] Amvrosieva, T.V., Diakonova, O.V., Boguch, Z.F., Kazinetc, O.N. Main directions to improve sanitary virological control of drinking water quality. Proceedings of the $5^{\text {th }}$ International Congress: "Water, Ecology, Technology - ECWATECH”, p.487, Moscow, 2002.

[4] Kaskarova, G.N., Blagova O.E. Significance of coliphages in assessment of viral pollution of water. Proceedings of the $5^{\text {th }}$ International Congress: “Water, Ecology, Technology - ECWATECH”, p.681, Moscow, 2002.

[5] Nedachin, A.E., Sanamyan, A.G., Dmitrieva, R.A. Comparative estimation of efficiency allocation of viruses from water with use of a membrane filtration method. Proceedings of the $5^{\text {th }}$ International Congress: "Water, Ecology, Technology - ECWATECH", p.479, Moscow, 2002.

[6] Drinking water. The hygienic demands and the quality surveillance, Uz DSt (Uzbek State Standard), 950:2000. 